\title{
ON THE FAMILY AND FAMILY LAW IN THE CZECH REPUBLIC
}

\author{
ZDEŇKA KRÁLÍČKOVÁ
}

\section{Introduction}

This chapter focuses on family, family life, and family law in the Czech Republic. Special attention is paid to various forms of family and family life and their legal backgrounds, as everybody has the right to choose their ways of life according to their wishes, needs, preferences, and options. That is why the concepts of marriage, registered partnership, and de facto cohabitation are discussed. This analysis is followed by a comparison of the rights and duties among family members within different models of family life. As there are often minor children in families, the subsequent lines of argument are devoted to establishing parenthood, the concept of parental responsibility in light of the best interests of the child, the participation rights of the child, and family solidarity and support. Finally, civil law provisions against domestic violence were introduced because of pathological phenomena in many families. Such behavior is far more visible these days and the lawmaker's eyes are not closed anymore.

Zdeňka Králíčková (2021) On the Family and Family Law in the Czech Republic. In: Tímea Barzó, Barnabás Lenkovics (eds.) Family Protection From a Legal Perspective, pp. 77-110. Budapest-Miskolc, Ferenc Mádl Institute of Comparative Law-Central European Academic Publishing. 


\section{The family and forms of family life}

Following the political, social, and economic changes in the Czech Republic after 1989, the structure of the family has undergone a complete change. Understanding Czech history can help clarify the demographic developments concerning society and family law in the Czech Republic. ${ }^{1}$ One does not need to have a degree in sociology to notice that fewer children are being born and that fewer marriages are being concluded in recent years. However, this trend seems to be changing. The divorce rates are still very high. Consequently, there are many non-complete and patchwork families. The number of children born out of wedlock is still very high. All of this has brought about a lot of difficulties for both children and single mothers. Some sociologists speak about individual problems like the feminization of property, among others. Unfortunately, there are no general reports, studies, or books describing the evolution of family and family life in the Czech Republic. ${ }^{2}$ However, the evolving nature of the family may become clear from the statistical data provided by the Czech Statistical Office, ${ }^{3}$ especially those collected for the Eurostat. ${ }^{4}$ It might be interesting to note that:

- a quarter of the population aged 20 years and over are single,

- first marriages are concluded 4 years later than at the turn of the century,

- there is an increase in the divorce rates among those in long-lasting marriages,

- cohabitation has become more popular than marriage among the youngest couples. $^{5}$

Proportions of marriage and divorce can be seen in the following chart of the next page. ${ }^{6}$

1 For a general historical point of view see Bělovský, 2009, p. 463 ff. For a more detailed overview, see Králíčková, 2008, p. 173 ff.

2 There are some exceptions. For instance, see: Možný, 2011.

3 Czech Statistical Office, no date a.

4 For more statistical data, and details on the historical development, family law, succession law, and international private law, see Králíčková, Kornel, Zavadilová, 2019, pp. 122-159; Ministry of Labour and Social Affairs of the Czech Republic, 2021.

5 Němečková, Kurkin, Štyglerová, 2015.

6 Czech Statistical Office, no date b. 
Marriages and divorces, 1950-2019

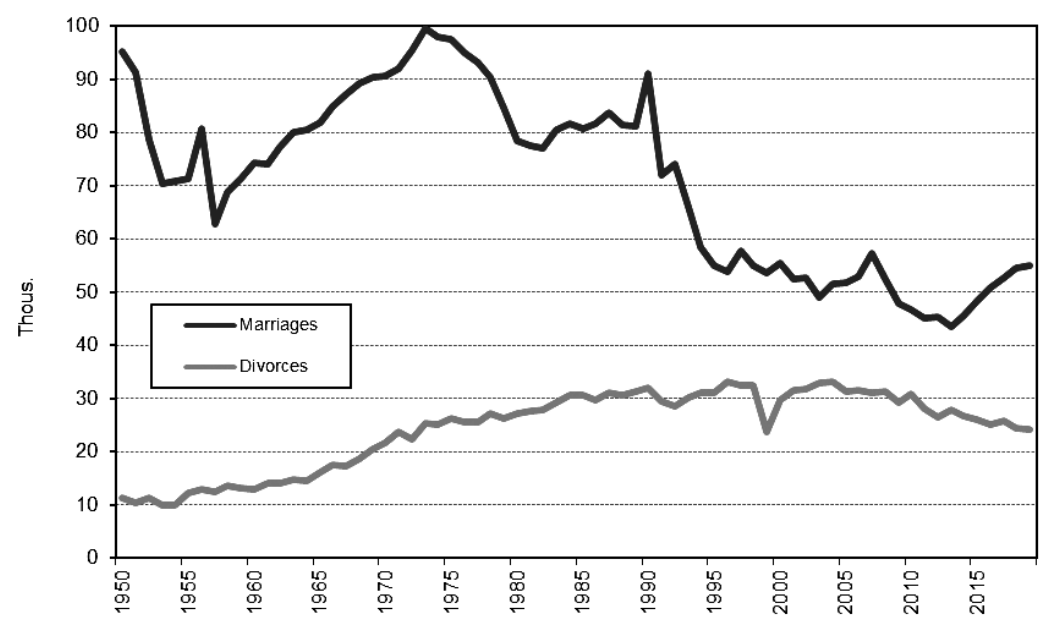

The following chart shows the number of children born out of wedlock. ${ }^{7}$

Proportion of live births outside marriage, 1950-2019

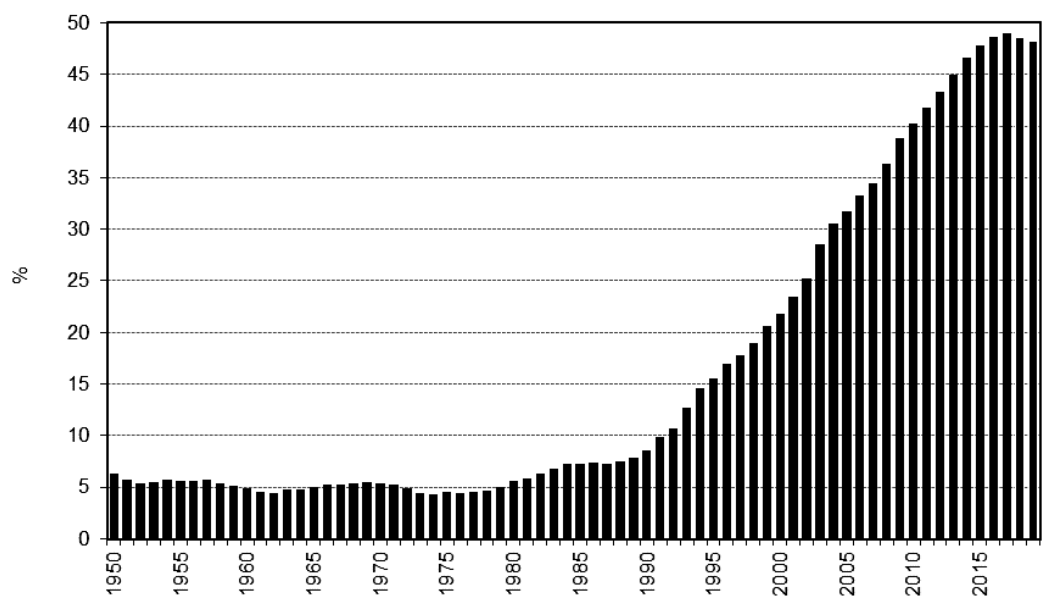

The single lifestyle was not accepted much in the past. It was not convenient to live without marriage. Nowadays, the polls show that there are a lot of one-person households in addition to one parent-families comprising a mother and child. The Czech Statistical Office does not provide official data on registered partnerships among samesex couples in comparison with marriage. However, non-official sources indicate that

7 Czech Statistical Office, no date c. 
the interest levels in registered partnerships occurred right after new Act was enacted in the Czech Republic in 2006 (for more on the legal developments, see below). Then the figures slumped, but after a few years, a gradual increase in the number followed. According to non-official sources, registered partnerships were concluded by 2,174 couples by the end of 2015. Gays were more interested in the vital step than were lesbians. Registered partnerships had been concluded by 1,439 male and 735 female couples. The interest has been rising over the past few years. On the other hand, some 300 couples ended their registered partnerships. ${ }^{8}$ Finally, there was the Populations and Housing Census in Spring 2021 which may show different figures and can help draw topical portraits of the family and family life in the Czech Republic. ${ }^{9}$ The COVID-19 crisis has significantly influenced families in the Czech Republic and beyond, but it is still far too early to see the changes clearly, let alone to comment on them.

\section{On the human rights dimensions of family, family life, and family law}

The Convention for the Protection of Human Rights and Freedoms protects the right to respect for private and family life of everyone (see art. 8). The case law of the European Court of Human Rights describes the Convention as "a living" instrument that provides protection to all forms of families and all models of family life. The Charter of Fundamental Rights and Freedoms ${ }^{10}$ is fully in harmony with the abovementioned concept of family life as guaranteed by international instruments. It contains general rules as well, indicating that "Parenthood and family are under the protection of the law" (art. 32, Section 2). The law does not limit families to those based on marriage alone. However, there is a pending draft lodged by a group of deputies that aims to create a constitutional ban for anchoring "marriage for all" according to another pending draft (see below, 5.1.). According to the first draft amendment, the new version of the Charter of Fundamental Rights and Freedoms should state expressis verbis that "Parenthood, the family and marriage as a union of a man and a woman are under the protection of the law." ${ }^{\prime 11}$ Especially because of many human rights covenants and the case law of both the Constitutional Court of the Czech Republic and the European Court of Human Rights, family law began to be amended, interpreted, and applied in harmony with its human rights dimension. A lot of changes to the previous legal regulation, especially the old law from the 1960s, occurred after $1989 .{ }^{12}$

8 Prague Monitor, 2016.

9 Scitani, 2021.

10 Act No. 2/1993 Coll.

11 Parliament of the Czech Republic, Chamber of Deputies, Parliamentary term No. VIII., Draft No. $211 / 0$.

12 Haderka, 1996, pp. 181-197; Haderka, 2000, pp. 119-130. 


\section{Family law according to the Civil Code: A return to tradition?}

In 2012, after a long "transitory" period, ${ }^{13}$ the new Civil Code was adopted in the Czech Republic (CC). ${ }^{14}$ It came into effect on January 1, 2014. ${ }^{15,16}$ The main authors of the Civil Code ${ }^{17,18}$ did not intend to include Family Law alone under the Civil Code - Book Two, but rather sought to return Family Law to the basics of the General Civil Code ${ }^{19}$ and eliminate the ideology and influence of Soviet Family Law. ${ }^{20}$ The return to the tested European tradition cannot be linked with the systematic nature of the Civil Code alone, but with its content as well. Individual provisions have incorporated important innovations that have been present in other European Civil Codes for a long time and results of various academic activities that originated especially in the Commission on European Family Law (CEFL). ${ }^{21}$ This is why the Civil Code may be considered a reasonable compromise that addresses both traditions and new phenomena, models and tendencies. The basic principles, values, starting points, and rules of interpretation and application can be found in Book One-General Part. The Civil Code emphasizes on the application of autonomy of the will in contrast to the legal regulation from the 1960s. It provides that unless expressly prohibited by the law, people may agree upon rights and duties differently from the law; only agreements contravening "good manners, public order or rights relating to the status of persons including right to protection of personality are prohibited" (Section 1, SubSection 2, CC). Autonomy of will is fully manifested in Family Law especially in marital property law (Section 708, CC). There are reasonable limits, such as concept of the special regime of things forming the usual equipment of the family household (Section 698, CC). Besides the Civil Code, the Act on Registered Partnership ${ }^{22}$ is a separate source of family law. The rules regulating the rights and duties of samesex partners were not incorporated into the Civil Code in 2012 although it was planned.

13 Králíčková, 2009, pp. 157-173.

14 Act No. 89/2012 Coll., Civil Code.

15 Králíčková, 2014, pp. 71-95.

16 Changes in Family Law introduced by the Civil Code were accompanied by the new civil law procedural legislation. See mainly Act No. 292/2013 Coll., on Special Civil Proceedings, and Act No. 202/2012 Coll., on Mediation.

17 Eliáš, Zuklínová, 2001.

18 Eliáš, Zuklínová, 2005.

19 Viz Allgemeines bürgerliches Gesetzbuch from the June 1, 1811 No. 946 Coll., that was taken by the Act from October 28, 1918 No. 11 Coll. to the legal order of the newly established Czechoslovakia.

20 Hrušáková, 2002; Hrušáková, Westphalová, 2011.

21 CEFL Online, no date.

22 Act No. 115/2006 Coll. 


\section{Marriage: A privilege and beneficial legal model for men and women}

\subsection{General}

Book One of the Civil Code, the General Part, expressly protects the family established by marriage (Section 3, Sub-Section 2, Para b), CC). However, there is no definition of family and family members in both Books One (General Part) and Two (Family Law). The Civil Code allows marriage to be solemnized only between a man and a woman (see Section 655 CC). ${ }^{23,24}$ Gender-neutral marriages were not discussed during the preparation of the Civil Code at all despite recent development in several European countries. ${ }^{25}$ There was a pending draft lodged by a group of deputies in the Parliament of the Czech Republic at the time of this study, which was in favor of gender-neutral marriages. ${ }^{26}$ Some consider the draft progressive and modern, whereas others have considered it a step undermining traditional family values. A more correct expression could be alternative. ${ }^{27}$ The draft calls for a radical change in the concept of marriage regulated by the Civil Code. Section 655 CC provides that "Marriage is a permanent union of a man and a woman formed in a manner provided by this Act." Should the pending draft mentioned above be passed, the relevant Section would provide thus: "Marriage is a permanent union of two people formed in a manner provided by this Act." The pending draft will not change the current regulation of affiliation. There will be no gender-neutral parentage in gender-neutral marriages. Finally, the Act on Registered Partnerships will be cancelled.

On the other hand, the second pending draft lodged by another group of deputies is very conservative. It seeks to protect the traditional model of families and suggests an amendment to the Charter of Fundamental Rights and Freedoms as mentioned above. If this amendment is passed, it would ban potential changes to the Civil Code toward establishing "marriage for all." Marriage would remain a traditional concept. No matter how the Civil Code expressly protects the family established by marriage (Section 3, Sub-Section 2, Para b), CC), it is necessary to mention that informal unions of a man and woman, or anyone, also enjoy protection in connection with the Convention for the Protection of Human Rights and Freedoms as they are guaranteed by the

23 As for transsexuals, the new law regulates change of sex (Section 29, CC), establishing that the change of sex of a person occurs on the surgical operation disabling the reproduction functions and changing the sex organs. The day of the change of sex is the day recorded in the certificate issued by the provider of health services. The change of sex does not affect the personal state of a man/ woman or their personal and property situation. Marriage or registered partnerships cease to exist. Details are included in Act No. 373/2011 Coll., on Specific Health Services.

24 Králíčková, Hrušáková, Westphalová al., 2020, p. 1 ff.

25 Sörgjerd, 2012, p. 167 ff.; Scherpe, 2016, p. 40 ff.

26 Parliament of the Czech Republic, Chamber of Deputies, Parliamentary term No. VIII., Draft No. $201 / 0$.

27 Masaryk University, 2018. 
right to respect for private and family life (art. 8, the Convention, in connection with Section 2, Sub-Section 2, CC, referring to the constitutional order).

\subsection{The nature and purpose of marriage}

The Civil Code states that marriage is a permanent union of a man and a woman originating in a manner prescribed by law. The main purpose of marriage is to establish a family and facilitate the proper upbringing of children (even if marriage may be entered into by people who are not in the "fertile" age) and mutual support and help (Section 655, CC), which fully reflects the principle of solidarity. Despite the fact that marriage is characterized by the word "permanency," divorce is a legitimate manner of terminating marriage.

\subsection{Solemnization of marriage}

Civil marriages used to be obligatory forms of marriage according to Communist Family Law. Although religious marriages were reintroduced into the Czech legal order shortly after 1989, in 1992, many drafts of the new Civil Code recognized only civil marriage under European standards. Nevertheless, in the course of the legislative process, religious marriage was included in the Civil Code. ${ }^{28}$ Thus, an engaged couple may be married in either in civil or religious ways (Section 657, CC). The marriage ceremony must be preceded in both forms by pre-marriage proceedings before a state authority where the following issues are examined (Section 673 and the following ones, $\mathrm{CC}$ ):

a) the sex of the potential spouses, ${ }^{29}$

b) the age of the potential spouses (18 years or over), ${ }^{30}$

c) legal obstacles to marriage such as the existence of another marriage or registered partnership, family relationship in a direct line and between siblings, the existence of guardianship or any other form of custody, and mental disorder and lack of legal capacity.

A marriage comes into existence when the potential spouses publicly and solemnly declare in the presence of two witnesses that they enter together into marriage. The record in the register of marriages is made only for registration purposes. The law makes it possible for the spouses to declare at the wedding ceremony that

a) one of their surnames will be their common surname, or

28 Religious marriage may only be solemnized before registered churches and religious societies with special authorization under Act No. 3/2002 Coll., on Churches and Religious Societies. There were 21 authorized churches and religious societies at the time of writing.

29 As for transsexuals, see note No. 23.

30 There are exceptions: the court may allow a minor who is not fully legally competent and is over 16 years to enter into marriage if there are serious reasons for it (Section 672, CC). 
b) both of them will keep their own surnames, ${ }^{31}$ or

c) one of their surnames will be their common surname, and the other, whose surname is not the common one will add his or her surname to their common surname in the second place (Section 660, CC).

If the requirements stipulated by the law for the solemnization of marriage are breached, the sanctions are as follows:

a) the regime of apparent marriage (matrimonium putativum), which originates ex lege, for example, when the registered church did not have special authorization under law etc. (see above), or

b) the regime of invalid marriage (non-matrimonium), which must be pronounced by the court, for example, in the case of bigamy or kinship etc.

\subsection{Rights and duties of spouses}

Rights and duties of spouses are traditional, especially the personal ones. The law is based on the equality of a man and woman in marriage, family, and society, and draws on previous legal regulations. Spouses are obliged to respect each other, live together, be faithful, mutually respect each other's dignity, support each other, maintain the family union, create a healthy family environment, jointly take care of their children (Section 687, CC), represent each other (Section 696, CC), and jointly manage the issues of the family (Section 693, CC, and Section 694, CC). The law indicates that each spouse has the right to be told by the other about his or her income and the state of his or her property and about the existing and planned work, studies, and similar activities. Each spouse is obliged, while choosing work, studies, and similar activities, to take into consideration the interests of the family, the other spouse, and the minors who have not attained full legal capacity yet, and who live with the spouses in the family household, and potentially, the interests of other members of the family (Sections 688 and 689, CC).

The Civil Code paraphrases previous regulations establishing that each spouse contributes toward the needs of the family and the family household according to their personal and property conditions and abilities and possibilities so that the standard of living of all members of the family can be the same. Providing property has the same importance as personal care for the family and its members (Section 680, CC). Besides the duty to contribute to the needs of the family, the law also imposes mutual maintenance duty on the spouses, to the extent of fulfilling the right to the same living standard (Section 697, CC). There is an innovative component, wherein the law regulates the concept of things forming the usual equipment of the family household (Section 698, CC). Regardless of ownership, one spouse needs the consent of the other while

31 If the spouses keep their existing surnames, they will also declare, at the wedding ceremony, the surname that will be used for their common children (Section 661, CC). Therefore, children cannot have double surnames. 
dealing with things that fulfil the life needs of the family. This does not apply if the thing is of a negligible value. A spouse may claim the invalidity of a legal act by which the other spouse dealt, without his or her consent, with a thing belonging to the usual equipment of the family household. Another innovative component is the regulation of a family enterprise (Section 700, CC), which is defined as an enterprise in which the spouses work together, or at least with one of the spouses working with their relatives to the third degree, or persons related to the spouses by marriage up to the second degree, and the enterprise is owned by one of them. Those who permanently work for the family or the family enterprise are considered members of the family and are deemed to participate in the operation of the family enterprise. Members of the family who participate in the operation of the family enterprise also participate in its profits and in things that are earned or gained out of those profits as well as in the growth of the enterprise to the extent corresponding to the amount and kind of their work. A person with full legal capacity may waive this right by making a personal declaration to such effect (Section 701, CC). If the family enterprise is to be divided, a member participating in its operation has a pre-emptive right to it (Section 704, Sub-Section 1, CC).

Community property is the key concept of marital property law, which was reintroduced into the Czech legal order in 1998 by the amendment of the Act on the Family. ${ }^{32}$ The legal regime of community property is regulated. It includes what one or both of the spouses have gained in the course of their marriage except for (Section 709, CC):

a) what serves the personal needs of one of the spouses, ${ }^{33}$

b) what only one of the spouses has gained by gift, succession, or bequest unless the donor or testator in the will expressed a different intention,

c) what one of the spouses has gained as compensation for a non-proprietary infringement of his or her natural rights,

d) what one of the spouses has gained by legal dealings relating to his or her separate property, and

e) what one of the spouses has gained as compensation for damage to or loss of separate property.

Community property includes profit from the separate property of one of the spouses. It does not include an interest of a spouse in a company or cooperative if that spouse has become a member of such company or cooperative in the course of the marriage, with the exception of a housing cooperative (Section 709, CC). It also includes debts assumed in the course of the marriage unless:

a) the debts concern the separate property of one of the spouses-to the extent of the profit from that property, or

32 Psutka, 2015.

33 Since 1998, the things one uses for the performance of one's job have not been excluded from the scope of the legal regime of community property. For a different opinion, see Boele-Woelki et al., 2013. 
b) only one of the spouses has assumed them without the other spouse's consent and it was not within the fulfillment of everyday or common needs of the family (Section 710, CC).

The new law enables not only modifications of the statutory regime of community property but the creation of the agreed regime as well (Section 716, CC) and the establishment of the regime of separated property (Section 729, CC). It is possible to conclude arrangements for the case of the termination of marriage by divorce or death by making a contract of succession (Section 718, Sub-Section 2, CC). Both potential and actual spouses may do so at any time: before entering into and during the marriage. By this, lawmakers fully respect the principle of autonomy of will to create $a$ wedding contract. This was not permitted by the law in the 1960s. The parties to the contract are only required to maintain the formality of a public deed. A record in the public list is optional (Section 721, CC).

The protection of a weaker spouse and third persons is expressly established in the Civil Code under a separate provision. A wedding contract for a marital property regime may not, because of its consequences, exclude the spouse's ability to maintain the family and affect, by its content or purpose, the rights of a third person unless such third person agrees to it; a contract made without the third party's consent has no legal effects for such a party (Section 719, CC). The law establishes that if, during the existence of community property, a debt has arisen only for one of the spouses, the creditor may achieve satisfaction in the execution of the judgment recovering the debt from the community property, too (Section 731, CC). If a debt has arisen only for one of the spouses against the will of the other, who communicated his or her disagreement to the creditor without unnecessary delay after coming to know about the debt, the community property may be affected only up to the amount that would be the share of the debtor if the community property were cancelled and divided (pursuant to Section 742, CC). This also applies in the case of a spouse's duty to pay maintenance, or if the debt comes from an illegal act of one of the spouses, or in the case of the debt of one of the spouses having arisen before entering into the marriage (Section 732, CC).

The new provision protecting family dwelling is important because the previous legal regulations belittled this issue. If the family house or flat is in the community property of the spouses, their position is equal and protection is provided by the regulation analyzed above. If not, the situation of the economically weaker spouse is dealt with under the Civil Code by defining the derived legal reason for housing (family dwelling). The law establishes that if the spouses' dwelling is a house or a flat in which one of the spouses has an exclusive right to live, and if it is a different right from the contractual one, by entering into marriage, the other spouse obtains the right to housing (Section 744, CC). If one of the spouses has an exclusive contractual right to the house or flat, especially a lease right, by entering into marriage, both spouses jointly obtain the lease right, thus ensuring the equality of rights and duties (Section 745, CC). It may be contractually agreed in a different way (Section 745, 
Sub-Section 2, CC), which is fully in harmony with the principle of autonomy of will. This can be done within the scope of a wedding contract.

The law regulates the prohibition of the disposal of the family dwelling in a manner similar to the regulation to the things forming the usual equipment of the family household (Section 698, CC; for details see above). If at least one of the spouses has the right to dispose of the house or the flat in which the family household is situated and the house or the flat is necessary for the dwelling of the spouses and the family, that spouse must refrain from and prevent anything that may endanger the dwelling or make it impossible. A spouse cannot, without the consent of the other spouse, misappropriate such a house or flat, or create a right to the house, to part or whole of the flat, the exercise of which is incompatible with the dwelling of the spouses or the family, unless he or she arranges a similar dwelling of the same standard for the other spouse or family. If a spouse acts without the consent of the other spouse contrary to this rule, the other spouse may claim the invalidity of such legal conduct (Section 747, CC). If the spouses have a joint right to a house or flat in which the family household of the spouses or of the family is situated, the abovementioned prohibition applies (Section 748, CC).

\subsection{Dissolution of marriage}

The Civil Code sets forth that marriage can be terminated only for the reasons established by law (Section 754, CC). Drawing on previous legal regulations, these reasons are: death and declaration of someone as dead (Section 26, CC), divorce (Sections $755 \mathrm{ff}, \mathrm{CC}$ ), and a surgical change of sex wherein the marriage is deemed terminated on the day recorded in the certificate of sex change issued by the provider of health services (Section 29, CC). ${ }^{34}$

The legal regulation of divorce is based on the irretrievable breakdown of marriage, which was the only reason for divorce introduced in the Act on the Family as early as in 1963. The new Civil Code sets forth the idea that marriage may be dissolved if the joint life of the spouses is deeply, permanently, and irretrievably broken down and its recovery cannot be expected (Section 755, Sub-Section 1, CC). The court deciding on the termination of a marriage shall examine the fact of the breakdown of the marriage and reasons leading to it (Section 756, CC). This variant is called contested divorce. However, if the spouses have agreed to the divorce, or the other spouse has joined the petition for divorce, the court does not examine reasons for the breakdown if the statements of the spouses on the breakdown of their marriage are identical and their intention to attain a divorce is true (Section 757, CC). This is called uncontested divorce..$^{35}$ The following requirements must be met:

34 See note No. 23.

35 The new legal regulation does not acknowledge consensual divorce. For more, see Boele-Woelki, Ferrand, González-Beilfuss, Jänterä-Jareborg, Lowe, Martiny, Pintens, 2004. 
a) on the day of the commencement of the divorce proceedings, the marriage should have lasted for one year at least and the spouses should not have lived together for more than six months,

b) the spouses, who are parents of a minor child without full legal capacity, should agree on the arrangements for the child for the period after the divorce and the court should approve their agreement, ${ }^{36}$

c) the spouses should have agreed on the arrangement of their property, their housing and, as the case may be, the maintenance for the period after the divorce; the property contract must be in writing with officially authenticated signatures.

Like the previous law, which was amended in 1998, the new law establishes a clause against harshness. It indicates that despite the breakdown of their marriage, it cannot be dissolved if doing so goes against:

a) the interests of a minor child of the spouses because of special reasons; the court examines the child's interest in the marriage by interrogating a custodian appointed by it for proceedings concerning the child's custody following the divorce,

b) the interests of the spouse who was not predominantly involved in the breach of marital duties and who would suffer especially serious harm by the divorce, when there are extraordinary circumstances supporting the subsistence of the marriage, unless the spouses have not lived together for at least three years (Section 755, Sub-Section 2, CC).

If the spouses have a minor child, the court will not grant a divorce until the special court dealing with the agenda on minors decides on the custody of the child for the period after the divorce (Section 755, Sub-Section 3, CC). The court dealing with the custody of the minor child may decide on or approve the agreement between the spouses on entrusting the minor child into individual (sole) custody of one parent, or alternating (serial) or joint custody of both parents (Section 907, CC). Both parents of the child are principal holders of the rights and duties resulting from parental responsibility (cf. Section 865 and further, CC) and the decision on custody after divorce determines who the minor child will live with, in the common household (besides the maintenance duty toward the child and visiting rights).

There is another pending draft ${ }^{37}$ in the Parliament of the Czech Republic that aims to make the position of divorcing parents of the minor child equal or at least similar to the position of non-married parents of a minor child who separate without any interventions by the state through their own informal mutual agreements. The pending draft is based on the idea that the parents of a minor child know their child

36 There should be changes. For more, see note No. 37.

37 Parliament of the Czech Republic, Chamber of Deputies, Parliamentary term No. VIII., Draft No. $899 / 0$. 
well and seek to safeguard the best interests of the child even when they decide to separate. Should the draft be passed, the divorce of a husband and a wife-who can agree on divorce and on property and dwelling consequences of the divorce and on a post-divorce arrangement regarding their minor children-would be amicable, smooth, and quick. The divorcing couple will have to submit only the common motion for a divorce, the property and dwelling contract, and the agreement on the custody, maintenance, and if the case may be, the visiting rights of the minor child, to the judge. The judge dealing with the divorce will not have to approve the property contract and the agreement on custody and maintenance of minor children.

\subsection{Legal consequences of the dissolution of marriage}

Dissolution of marriage affects the status and property of the ex-spouses. If a marriage is terminated by death, or by the declaration of one of the spouses dead, the deceased's property passes to the spouse according to the first inheritance class of heirs together with the decedent's children (Section 1635, CC). The new Civil Code gives the surviving spouse a privileged position. If there are no children, the property passes to the spouse in the second class of heirs together with the decedent's parents and cohabiting persons or those who share the same household (Section 1636, CC). However, in keeping with the previous law, the surviving spouse is not a forced heir who is entitled to an obligatory share (cf. Section 1642 and further, CC) as the regulation provides that "Forced heirs include the decedent's children and, if they do not inherit, their descendants" (Section 1643, Sub-Section 1, CC).

Nevertheless, if there is a will, for example, in favor of third persons, the Civil Code establishes that the surviving spouse gains possessory title to things forming the basic equipment of the family household (Section 1667, CC) and the right to maintenance from the inheritance arises for him or her (Section 1666, CC). Special protection is ensured for the surviving spouse in relation to dwelling. The law regulates the transition of a joint lease of a flat ex lege (Section 766, CC) and the discretion of the court to create an easement of dwelling for the surviving spouse if he or she has custody of a minor child-the easement being for a definite term and for payment corresponding to the usual rent (Section 767, Sub-Section 2, CC).

If the marriage was terminated by divorce, it is necessary, to first settle and adjust the community property of the spouses. As a rule, the law requires an agreement between the divorced spouses. If the agreement is not secured, the court will decide based on both quantitative and qualitative criteria like the interests of the unsupported children or the extent to which a spouse was involved in achieving and maintaining the property value falling within the community property of the spouses (Section 742, CC). If, within three years from the divorce, no agreement is made or petition filed, a legal presumption will be applied (Section 741, CC). The law states that "If, within three years from reduction, cancellation or extinction of community property, no settlement of what was formerly part of the community property takes place, 
even by agreement, and no application for settlement by a court decision is filed, the spouses or former spouses are conclusively presumed to have settled as follows:

a) corporeal movable things are owned by the spouse who uses them exclusively as an owner for his own needs or the needs of his family or family household,

b) other corporeal movable things and immovable things are under undivided coownership of both spouses; their shares are equal,

c) other property rights, claims and debts belong to both spouses jointly; their shares are equal."

The spouses' dwelling after the divorce depends on the legal basis of their marital housing arrangement. If the house used for family dwelling was in the community property of the spouses, all that has been said above in connection with its settlement and adjustment will apply. If it was a joint lease of a flat by the spouses, they may cancel it by rescinding the contract or seeking recourse to the court that will determine, while deciding on cancelling the joint lease, the manner of compensation for the loss of the right considering the situation of unsupported children, and the opinion of the lessor among others (Section 768, Sub-Section 1, CC). If one of the spouses was an exclusive owner of the house or flat used for family dwelling, the other spouse loses by divorce legal reason for housing and the court may decide about his or her moving out (Section 769, CC).

The maintenance duty between divorced spouses is regulated in the Civil Code in a manner different from that under the previous law. ${ }^{38}$ The basic presumption is $d e-$ pendence on maintenance, or incapacity to maintain oneself independently. The law has established that such an incapacity to maintain oneself independently has to have its origins in or connections to the marriage (Section 760, Sub-Section 1, CC). Another innovation is the list of factors that should be taken into consideration while deciding on maintenance. The court will consider the duration of the marriage, the date of dissolution, and whether (Section 760, Sub-Section 2, CC):

a) the divorced spouse has remained without a job despite not being prevented from finding a job because of serious reasons,

b) the divorced spouse could have ensured maintenance by properly managing his or her property,

c) the divorced spouse participated during the marriage in care for the family household,

d) the divorced spouse has not committed a criminal act toward the ex-spouse or his or her close person, or

e) whether there is another, similarly serious reason.

The scope of maintenance is established by the threshold of adequacy. The right to maintenance for a period after the divorce terminates only when the beneficiary enters into marriage, or by death of the obligor or the beneficiary. If a substantial 
change in the situation occurs, the court may decide on decreasing, increasing, or abolishing the mutual duty of maintenance between the divorced spouses.

The new Civil Code also establishes an exceptional right to sanctioning maintenance to the extent of ensuring the same living standard. The spouse that did not cause or agree with the divorce and who suffered serious harm because of the divorce may file a motion before the court to impose a maintenance duty on the former spouse to such an extent that ex-spouses can have the same living standard. The divorced spouse's right to maintenance may be considered justified only for a period adequate to the situation but for no longer than three years after the divorce (Section 762, CC).

\section{Registered partnership between same-sex partners according to a separate act}

A registered partnership between persons of the same sex should have been regulated by the Civil Code. However, as conservatism prevailed in the course of legislative work, the rules regulating the status of the union between persons of the same sex were taken out of the draft. Thus, the Act on the Registered Partnership continues to operate. ${ }^{39}$ According to the Act on Registered Partnership, some rights and duties of registered partners are similar to those of spouses, for example, mutual maintenance duty based on the same living standard (Section 10, ARP), or former spouses, for example, mutual maintenance duty of an adequate standard or to match the same living standard in the case of sanctioning maintenance (Section 11, ARP). In many ways, the rights and duties of registered partners are identical to the position of those in informal unions and de facto cohabitation.

There is a special rule in the Civil Code, which stipulates that "The provisions of Book One, Book Three and Book Four on marriage and on the rights and duties of spouses apply by analogy to registered partnership and the rights and duties of partners" (see Section 3020, CC). In the case of death, the surviving partner has the same succession rights as the surviving spouse, in keeping with the relevant provisions under Book Three-Absolute Property Rights, Title III Law of Succession.

In harmony with the abovementioned special rule, the Civil Code provides that the provisions regulating Family Law included in Book Two do not apply to registered partners (Section 3020, CC). It means that, for instance, there is no community property and no common lease of flats by operation of law, no protection of family dwelling and no protection by the provisions regulating things forming the usual equipment of the family household between registered partners.

39 Act No. 115/2006 Coll. (further mainly ARP). For details and critical comments, see Holub, 2006, pp. 313-317. 
Registered partners are not allowed to jointly adopt a minor child (see Section 800 , CC) or become foster parents of minors as only married couples can do it (Section 964, CC). However, in 2016, thanks to a case law before the Constitutional Court of the Czech Republic, there were some changes. The discriminatory provision that prohibited a single (unilateral) adoption by one of the partners during the subsistence of a registered partnership (Section 13, Sub-Section 2, ARP), was cancelled by the decision of the Constitutional Court of the Czech Republic. ${ }^{40}$

The Czech Republic has received several applications from men in relationships as legal parents of a minor child born abroad, out of surrogacy, for registration as parents in the Register of Births. There have also been various complaints and applications to the courts, such as the Supreme Administrative Court, the Supreme Court, and the Constitutional Court of the Czech Republic. The results vary as the same-sex partners may recognized as legal parents in foreign legal jurisdictions because of many legal instruments, such as presumptions by the operation of law, parental orders, adoption orders, and declarations of parentage (acknowledgments of parenthood). In contrast, provisions against domestic violence fully apply for registered partners as there are special assignations (Section 3021, CC). Of the two pending drafts-one supports gender-neutral marriage, and the other strengthens the position of the family based on marriage. Gender-neutral parentage does not have much support in Czech society.

\section{De facto unions: Popular in society, neglected by law}

While the Civil Code expressly protects families established by marriage (Section 3, Sub-Section 2, Para b), CC), informal relationships also enjoy protection in connection with the Convention for the Protection of Human Rights and Freedoms as they are guaranteed by the right to respect for private and family life (art. 8, Convention, in connection with Section 2, Sub-Section 2, CC, referring to the constitutional order). Owing to limited scope of the term "family" as regulated in the Civil Code, there are no articles that establish mutual rights and duties between the cohabitees, that is, there is no duty to help each other, no community property, no protection of family dwelling, and no concept of a common household and mutual maintenance by operation of law. Oftentimes, as there are no property contracts in place between

40 See the Ruling of the Constitutional Court of the Czech Republic No. Pl. ÚS 7/15, dated June 14, 2016. The Constitutional Court found the provision discriminatory as it indicated that registration is in itself an obstacle in the course of adopting a minor child by one of the registered partners. Available at: http://nalus.usoud.cz/Search/Search.aspx (only in Czech). There were dissenting opinions. 
the cohabitees, weaker parties face a lot of problems upon the dissolution of de facto relationships.

However, as there is no discrimination among children born out of wedlock, the rights and duties of the parents toward their children remain equal. If an unmarried man and an unmarried woman "have a child together," they are principally the holders of parental responsibility by operation of law. They are not treated differently when compared with the married parents of a minor child. However, parenthood must be legally established. There are no differences between the children, both in the personal and property spheres under Czech law.

The law traditionally protects property claims of the unmarried mother of a child. The Civil Code provides for "Maintenance and support, and provision for the payment of certain costs for an unmarried mother" as follows (Section 920, SubSection 1 CC): "If the child's mother is not married to the child's father, the child's father shall provide her with maintenance for two years from the birth of the child and provide her with a reasonable contribution to cover the costs associated with pregnancy and childbirth."

Section 920, Sub-Section 2 and 3 CC describe the property rights of a pregnant woman thus: "A court may, on the application of a pregnant woman, order the man whose paternity is probable to provide an amount needed for maintenance and a contribution to cover the costs associated with pregnancy and childbirth in advance. A court may, on the application of a pregnant woman, also order the man whose paternity is probable to provide in advance an amount needed to provide for the maintenance of the child for a period for which the woman would be entitled to maternity leave as an employee under another legal regulation." ${ }^{41}$

These provisions are often used in practice as statistics show that almost $50 \%$ of children are born out of wedlock in these days. For details the chart "Proportion of live births outside marriage, 1950-2019" above.

A surviving cohabitee is in a very weak position in practice as there is seldom a will addressing their interests. The law regulates the third inheritance class of heirs as follows: "If neither the spouse nor any of the parents inherit, decedent's siblings and those who lived with the decedent in the common household for at least one year before his death and, as a result, cared for the common household or were dependent in maintenance on the decedent, inherit in the third class of heirs equally" (Section 1637, SubSection 1, CC). ${ }^{42}$ The surviving cohabitee must prove many facts from their common life during the proceedings. ${ }^{43}$

41 It would be 28 weeks, in case of siblings or more children 37 weeks. For details see the Act No. 262/2006 Coll., The Labour Code (Section 195, Sub-Section 1).

42 The property situation of a surviving cohabitee is far more difficult if there is a child as he or she is considered a forced heir. If a deceased cohabitee is "formally" married of registered and his or her parents are still alive, the situation will be very different and complicated (Section 1636, CC).

43 Boele-Woelki, Ferrand, González-Beilfuss, Jänterä-Jareborg, Lowe, Martiny, Todorova, 2019. 


\section{Parents and children}

\subsection{General}

The Civil Code establishes that kinship is based on a blood tie or originates from adoption (Section 771, CC) which is constructed as a status change (cf. Section $794 \mathrm{ff}$, CC). The legal regulation of blood parenthood is traditional. The Civil Code regulates the establishment of a parent and identifies the child's parent through the application of mandatory rules. The child's mother is the one who gives birth to the child (see Section 775, CC) and the child's father is the one whose fatherhood is based on one of the three legal presumptions of paternity (Section 776 et seq., CC). In addition to legal parenthood (de jure), biological, genetic, and social parenthood (de facto) enjoy importance. It is necessary to respect the balance among legal, biological, and social parenthood. Therefore, the law also protects putative parents (e.g. Section $783, \mathrm{CC}){ }^{44}$

The legal regulations governing the adoption of a minor are in harmony with the international standards established mainly by international covenants and case laws from the European Court of Human Rights. The adoption of a major was abandoned for political reasons as a "bourgeois anachronism" after the communist takeover in 1948. Thus, the Civil Code reintroduced an adoption of a major. A child is the descendant in the direct line of the first stage (see Section 772 and Section 773, CC). A minor child is understood as a child who has not reached the age of majority, that is, the age of 18 years (Section 30, Sub-Section 1, CC). A minor fully non-capable child is aged under 18 years and has not reached full legal capacity by a decision of a court (see Section 37, CC) or by concluding a marriage (Section 30, Sub-Section 2, CC). Law provides special protection to minor fully non-capable children especially within the private law concept of parental responsibility and through public law.

\subsection{On motherhood: Mater semper certa est}

The old Roman law principle respecting the fact of birth has traditionally been considered the basis for creating the relationship between the mother and child, even if expressis verbis it was not introduced in the Czech legal order until 1998. The lawmakers respected the natural law idea of one mother and one father for each child while adopting the Civil Code. That is why the Civil Code provides thus: "The child's mother is the woman who has given birth to the child" (Section 775, CC). Despite being a relatively simple one, the new legal regulation of motherhood is formulated as $a$ mandatory rule from which it is not possible to deviate unilaterally (e.g. by giving up or abandoning a child, not expressing interest, etc.) or contractually (with or without payment). 
The basis of motherhood is the fact of birth, which includes assisted reproduction, too. The legal mother of a child is the woman who has gave birth to the child, regardless of who the donor of the egg was. Legal motherhood is identical to biological motherhood and in case of egg donation, genetic motherhood is irrelevant. ${ }^{45}$ Surrogate motherhood is not regulated in Czech law except for "one note" in connection with adoption among close relatives (see Section 804, CC).

Motherhood is a basic status that is important for the entire legal order. Maternal status is crucial for everybody. Therefore, it is necessary-in compliance with international obligations, especially art. 7 of the Convention on the Rights of the Child, to register a child soon after birth in connection with his or her mother, thus making his or her status in connection with the parents certain. Public law regulations establish this duty as a rule especially for the medical staff assisting with birth. Thus, anonymous child delivery is not in harmony with Czech law.

Despite these rules, there is a legal possibility for hidden childbirth according to a special legislation that was passed in $2004^{46}$ following some MPs' initiatives. This was followed by a new regulation recently. ${ }^{47}$ According to this law, a woman with permanent residency in the Czech Republic, if it is not a woman for whose husband there is a presumption of fatherhood, has a right to have her identity hidden in connection with birth. If such a woman who wants to hide her identity in connection with birth, submits to the health service provider of a written application asking for her identity in birth to be hidden, also indicating that she does not intend to take care of the child, the child has a mother but will not know her identity because it will be hidden from them in the register of births. The rights of biological fathers are more or less omitted in such cases. There has been another new social phenomenon in the Czech Republic since 2005. Owing to private funds, ${ }^{48}$ we face the reality of babyboxes for unregistered and unwanted children in the country. This enables mothers to leave their new-born babies there. If the identity of a mother who placed her child in the baby-box is not discovered, the child obtains the status of $a$ foundling.

\subsection{On fatherhood: Pater vero is est quem nuptiae demonstrant}

The new legal regulation determining fatherhood (Sections 776-793, CC) is based on three traditional legal presumptions drawing on probability. There are not many innovations in the Civil Code in this regard. Establishing legal parenthood is

45 The regulation of artificial insemination or assisted reproduction can be found in Act No. 373/2011 Coll., Act on Specific Health Services. This Act defines basic concepts such as assisted reproduction, infertile couple, anonymous donor, mutual anonymity of the donor, the infertile couple and their child, etc., and the conditions for realization, that is, informed consent, and various restrictions, as far as the age or kinship are concerned.

46 See Act No. 422/2004 Coll., so-called Act on hidden child birth. For critical comments, see Hrušáková, Králíčková, 2005, p. 53 ff.

47 See the Act No. 372/2011 Coll., on Health Services, Section 37.

48 Statim, 2021. 
traditional, despite the fact that legal presumptions of fatherhood were created when the legitimacy of a child was highly valued and when methods of assisted reproduction and paternity tests were in their infancy.

Thus, the first presumption is in favor of the mother's husband, if the child is born in wedlock or within 300 days since its termination (Section 776, CC). The second presumption respects the autonomy or will of the child's parents and is in favor of the man who has stated, together with the child's mother, that he is the father of her child (Section 779, CC). The third presumption is based on sexual intercourse in the critical period: the father of an unmarried woman's child is considered the man who had sex with her within the period of 160 days till birth and within the period not exceeding 300 days before birth unless his fatherhood is excluded by serious reasons (Section 783, CC).

However, there are some novelties ${ }^{49}$ as well:

a) Considering the fact that the Civil Code returns to the concept of declaring someone missing (cf. Section 776, Sub-Section 1, CC), which, within the context of the first presumption, has the same importance as the death of the mother's husband;

b) enabling the so-called conversion of the first presumption into the second one (cf. Section 777, Sub-Section 1, CC), that is, if a child is born in the interim period lasting from the filing of the petition for divorce till the $300^{\text {th }}$ day after the divorce, it is possible to consider the man the child's father if he declares thus and his statement is in conformity with the statement of the mother's husband, or the ex-husband, and with the statement of the child's mother;

c) Including the presumption of an unmarried mother's partner if he consented to artificial insemination (Section 778, CC);

d) Introducing new rules for making a consenting declaration on the second presumption;

e) Extending the denial period for the mother's husband if it is a denial of the first presumption from 6 months to 6 years since the birth of the child (see Section $785, \mathrm{CC})$;

f) Extending the denial period from 180-300 days to 160-300 days owing to artificial insemination for both the husband and the partner of the mother (Section 787, CC);

g) Introducing the option of judicially pardoning one for missing the denial preclusive period if it is required in the child's interest and by public order requirements (Section 792, CC);

h) Introducing the option for the court to start ex officio proceedings on denying fatherhood but only in the case of the second presumption in a situation where such a father cannot be the real father of the child and it is clearly required by the child's interest, and if the provisions guaranteeing the fundamental human rights are to be fulfilled (Section 793, CC).

49 The rights of the putative father to establish legal fatherhood even against the will of the child's mother were introduced into the previous act in 1998. 
Despite being planned, the child's denial right is not expressly regulated in the Civil Code even if it has never been put into question by expert committees. Denial rights of putative fathers were completely omitted by the lawmakers. The number of people who are actively legitimated for denying fatherhood is a traditional one-only the child's parents recorded in the Register of Births are allowed to challenge the child's status. As for the third presumption, conservatism prevailed even though the Constitutional Court and several family law experts concluded that its traditional basis, namely sexual intercourse within the so-called critical period, was antiquated by the revolutionary development of genetics. ${ }^{50}$

The newest development was inspired by the case law before the European Court of Human Rights: the cases of Paulík v. Slovakia ${ }^{51}$ and Novotný v. the Czech Republic. ${ }^{52}$ The Czech legislature allowed men designated by the court to be legal fathers under the third presumption of paternity when DNA tests did not exist, in order to reopen proceedings and reverse the effects of res judicata. ${ }^{53}$

\subsection{On the adoption of minors: adoption natura imitatur}

Since 1949, the adoption of minors has been understood as a benefit for real and social orphans, as well as for unwanted and abandoned minor children. Adoptive parents consider adoption the acceptance of a stranger's minor child as their own. Since 1963, the law regulated only the full adoption of minor children. The adoption of minors has been created as a status change and as a fiction of biological family ties. As a result of a number of international human rights laws, the Czech legal order has broadened the protection of a child's natural family, the minor parents of the child, and his or her putative parents or parents without full legal capacity. ${ }^{54}$

The new conception of adoption of minor children anchored into the Civil Code (Section 794 et seq., CC) primarily modifies the requirements of parental consent (Section 809 et seq., CC) and the option of consent withdrawal (Section 817, CC) or its expiry (Section 816, CC). The child's mother may give consent to adoption after the expiry of six weeks from the delivery, that is, after puerperium (Section 813, CC). The child's father can give consent at any time after the child's birth. If the child's parents are aged under 16 years, they are not allowed to consent to adoption at all (Section 811, Sub-Section 1, CC). Any consent so given would be irrelevant. The law has introduced a rule wherein a court may, while depriving the parents of their parental responsibility, also decide on the deprivation of the parental right to give consent to adoption (Section 873, CC).

50 Cf. the Judgement of the Constitutional Court of the Czech Republic from February 28, 2008, I. ÚS 978/07.

51 Application No. 10699/05.

52 Application No. 16314/13.

53 Act No. 296/2017 Coll., an amendment to the Act No. 292/2013 Coll., Act on Specific Civil Law Proceedings, that introduced the new Section 425a.

54 Králíčková, 2003, pp. 125-142. 
The law also addresses parental disinterest, by providing for a variety of situations, such as where a parent stays in an undisclosed location (Section 818, Sub-Section 1c, $\mathrm{CC}$ ) or shows no interest in the child, thus permanently culpably breaching his or her parental duties (Section 819, CC). The law establishes a presumption of apparent non-interest, when non-interest lasts at least three months since any instruction, advice, and assistance from the state authority (Section 820, CC). If there are close relatives of the child who are willing and able to care for the child personally, preserving family ties will always take precedence over adoption by a non-relative (Section 822, CC).

The child's participation rights guaranteed by international conventions have been strengthened. The law explicitly states that a child aged over 12 years should give consent to his or her adoption (cf. Section 806, CC) and that he or she may revoke his or her consent to adoption (Section 808, CC). If, at the time of adoption, the child was of a tender age, the adoptive parents have a duty to inform the adoptee about their adoption as soon as it is appropriate and no later than when the adoptee starts compulsory school attendance (Section 836, CC).

The total ban on adoption among close relatives has been lifted. Close family ties used to be a traditional disincentive for adoption. However, the legislature came under strong pressure and revoked this natural, social, and legal ban. Adoption is excluded among those who are relatives in the direct line and siblings except for kinship based on surrogate motherhood (Section 804, CC). Medical law has never regulated surrogate motherhood. ${ }^{55,56}$ However, surrogacy is a reality today. Private clinics provide surrogacy services without any legal regulation. As mentioned above, the child's mother is the one who delivered the child (Section 775, CC).

Discussions on same-sex adoption and adoption by de facto couples, have not led to any changes in the law around joint adoption. Only married couples can adopt a child jointly, although the Czech legal order regulates registered partnerships between persons of the same sex (see above). The law allows adoption by one of the spouses and exceptionally adoption by a single person (Section 800, CC).

The obligatory pre-adoption care was extended from three months to no less than six months (Section 829, CC). The new legal rule says that after the parents' consent to adoption and placing a child in the pre-adoption care of prospective adopters, the exercise of parental responsibility of the child's parents is suspended by operation of law (Section $825, \mathrm{CC}$ ) and the court must appoint $a$ guardian for the adoptee. The maintenance obligation of a child's parents or other persons is also suspended as prospective adoptive parents are required to have the child with them at their own expense (Section 829, CC).

The Civil Code also establishes the option of adoption and its circumstances to be kept a secret from the child's original family. The option of secrecy applies for the child's parents and their consent to adoption, too (Section 837, CC). However, once the child reaches the age of majority and legal capacity, he or she is entitled to know the details of the adoption (Section 838, CC). Regardless of this new rule, the traditional 
regulation on vital registers has allowed adoptees aged over 18 years to inspect the registry and related documents. ${ }^{57}$ This proves that adoption has never been based on the principle of anonymity.

Another new feature of the new regulation is the possibility of the court to order surveillance to determine the success of the adoption for a particular period, usually through the Child Protection Office (Section 839, CC).

There has also been a key change in the consequences of adoption: a revocable adoption is converted into an irrevocable one by the operation of law within 3 years after the adoption order becomes effective. No petition for the revocation of adoption is possible (Section 840 paragraph 2, CC). An exception applies to situations when the adoption was in conflict with law. However, the court may decide upon the irrevocability of an adoption even before the expiry of the three-year period from the date of the adoption order.

The previous rule on the surname of the adopted child was strict in that it mandated a change in the child's original surname to that of the adopters. This was altered, and the court may allow the adoptee to use both surnames together: the old and adopters' surnames (Section 835, Paragraph 2, CC). The new regulation, following tradition, also allows re-adoption, which refers to the adoption of an already adopted child (Section 843, CC).

\subsection{Adoption of an adult: A return to tradition}

The Civil Code restored the regulation of adopting an adult that prevailed before the communist takeover in 1948 and radical changes to family law were imposed in line with the Soviet pattern. The adoption of an adult is always a status change. However, unlike the adoption of a minor, it does not entail a full status change. The law distinguishes between two types of adoption of an adult:

a) one that is analogical to the full adoption of minors (Section 847, CC), and

b) one that is not analogical to the full adoption of minors (Section 848, CC), that is, not full adoption when the adoptee remains-especially with regard to property-connected with his or her family of origin (cf. Section 849, CC).

\section{On mutual duties and rights of parents and children: An overview}

The Civil Code pays significant attention to the mutual obligations and rights of parents and children (Section $855 \mathrm{ff}$., CC). The rules are built on equality and reciprocity of duties and rights of parents and children, regardless of their ages and levels 
of legal capacity. Many obligations and rights form an integral part of the lifetime of parents and children. A number of obligations and rights of parents in relation to their children concern only new-born children, such as the duty and right to name their child (Section 862, CC). Some obligations and rights arise from parental responsibility and form the substance of the legal relationship between the parents and minor children who are not fully capable (Section 865 et seq., CC). Similarly, some obligations and rights of children in relation to their parents concern only minor children. Others are established regardless of age, for example, maintenance. The legal regulation of parental responsibility is traditional in many ways, cf. the provisions governing the obligation of the child to heed his or her parents (Section 857, CC). A number of provisions are entirely new because it was necessary to meet the international obligations that bind the Czech Republic during recodification, such as reinforcing the parents and children's right to mutual personal contact in the case of separation or divorce between the child's parents, etc. (cf. Section 888, CC) ${ }^{58}$

Some mutual obligations and rights are permanent, although with the passage of time, the details may vary, such as the amount of reciprocal maintenance between parents and children (Section 910 et seq., CC), or the obligation to respect each other's dignity (cf. also Section 883, CC), or mutual assistance. Others, such as those belonging to parental responsibility (Section $865, \mathrm{CC}$ ) vary in relation to the gradual maturation of the child and disappear by the time the child becomes an adult or acquires full legal capacity. The equality and reciprocity between parents and children vis-à-vis obligations and rights are affirmed by the following statement: "the parents and the child have obligations and rights in relation to each other" (Section 855 , CC). The rights of one always correspond to the obligations of the other and vice versa. The same provision says that "these mutual obligations and rights cannot be waived; if they do so, it is disregarded." Neither the parents nor the children can "get rid of" any of their obligations or rights regardless of whether they are personal or proprietary, as they are established by law. The relationship between the parents and the child cannot be cancelled both unilaterally and by agreement. There is only one legal exception: the parents have a right to give their consent to the adoption of their child (see Section 809 et seq., CC). A lot of family agreements and contracts regarding the child can be concluded between the parents, between the parents and third persons, and between the parents and the child. However, the parents must always bear in mind the main purpose of their obligations and rights in relation to their child, which is to ensure the moral and material welfare of the child. The content of any agreement concerning non-routine matters in respect of a child's assets and liabilities must be assessed by courts. Private law provisions under the Civil Code are supplemented by public law regulations because it is necessary to protect children, as there is a public interest to protect them. ${ }^{59}$ 


\section{Parental responsibility}

\subsection{General}

Parental responsibility is a key concept in Czech Family Law. ${ }^{60}$ While codifying rules pertaining to parental responsibility, the authors of the Civil Code took into consideration a major part of the Principles of European Family Law regarding Parental Responsibilities created by the CEFL. ${ }^{61}$ This is why parental responsibility is based on the following categories of duties and rights of parents: (a) care, protection, and education of the child; (b) maintenance of personal relationships; (c) determination of residence; (d) administration of property, and (e) legal representation. The Civil Code governs the establishment, holding, and administration of parental responsibility in keeping with the best interests and welfare of the child. There are special provisions concerning decision-making on daily matters and important issues vis-à-vis the child. The agreement and cooperation of both parents are key factors under the Civil Code, and apply irrespective of whether they live together or are separated or divorced. However, if the parents cannot agree on important matters concerning the child, regarding the personal care (custody) of the child in particular, the court will decide on (a) individual (sole) custody by one parent, or (b) alternating (serial) custody, or (c) joint custody by both parents. The responsibility of one parent does not end with the placement of the child in the individual (sole) custody of the other after the dissolution or annulment of the marriage. It does not end with the factual separation of the parents, or with the placement of the child into some form of substitute care, such as foster or institutional care, etc. This issue must be considered in light of its human rights dimension. ${ }^{62} \mathrm{~A}$ child is an integral part of his or her family of origin. Both parents have a right to exercise parentage and associated rights and duties. The duties and rights belong to parental responsibility, both in theory and in practice. Following the Convention on the Rights of the Child, a child is not treated as an object of decision-making, but as an active person. The child's participation rights and the right to self-representation in legal proceedings are taken seriously. ${ }^{63}$

\subsection{The origin and duration of parental responsibility}

Parental responsibility arises ex lege for each parent at the birth of the child and ceases as soon as the child acquires full legal capacity (Section 30, CC). It is irrelevant whether the child's parents are married or not, or live together or not, although these factors can play a significant role, especially in the exercise of individual obligations

60 Králíčková, 2011, pp. 829-840.

61 Boele-Woelki, Ferrand, González-Beilfuss, Jänterä-Jareborg, Lowe, Martiny, Pintens, 2007.

62 Králíčková, 2010.

63 Schön, 2015, pp. 36-45. 
and rights arising out of parental responsibility. The duration and extent of parental responsibility may be changed by the court alone (Section 856 in fine, $\mathrm{CC}$ ).

\subsection{The holders of parental responsibility}

Under the new law, every legal parent has parental responsibility and the obligations and rights arising from it, unless he or she was deprived of them by a court (Section 865, CC). Minor parents of children and parents limited in terms of legal capacity as declared by court because of a mental disease also have obligations and rights arising out of parental responsibility. However, not every parent has a right or duty to exercise parental responsibility. Bearing in mind the best interests and welfare of the child, the law provides for the suspension of the exercise of parental responsibility ex lege owing to the immaturity or mental disorder of the parent in question (Section 868, CC). Parental responsibility cannot be transferred to another person, as the law indicates that parents and children cannot waive their mutual obligations and rights (Section 855, Sub-Section 1, CC). The law does not give the court such an option, either. A spouse (step-parent) or partner of the child's parent is not the holder of obligations and rights arising out of parental responsibility, although the law may allow him or her to participate in the upbringing of the child (Section 885, CC). A guardian is not the holder of parental responsibility, either (Section 928, CC).

\subsection{Scope of parental responsibility}

The Civil Code in relation to the Principles of European Family Law regarding Parental Responsibilities sets out the scope of obligations and rights of parents. It is currently wider than it was under previous legal regimes. Parental responsibility covers the duties and rights of parents and includes: (a) caring for the child, including, without limitation, care for his or her health, and physical, emotional, intellectual, and moral development, (b) the protection of the child, (c) maintaining personal contact with the child, (d) ensuring his or her upbringing and education, (e) determining the place of his or her residence, (f) representing him or her, and (g) administering his or her assets and liabilities (see Section 858, CC). The exercise of all these obligations and rights must be understood as the exercise of important duties and rights on which the parents must agree (with the exception perhaps of trivial, daily matters with respect to the child's property, see Sections 897 and 898, CC). The non-exhaustive list of important issues explicitly includes unusual medical and similar treatments, determining the place of residence, and choice of education or employment of the child (see Section 877, CC). Parental responsibility does not include:

a) maintenance obligation and right to maintenance, because its duration is not dependent on reaching maturity or full legal capacity by the child (Section $859, \mathrm{CC})$, and

b) the right to consent to the adoption of the child (Section 809, CC). 


\subsection{Obligations of parents to provide their child with care and to protect and raise the child}

Care for the child in the broadest sense of the term is a key part of parental responsibilities. It includes care of his or her health, and physical, emotional, intellectual, and moral development. It is different from personal care within individual (sole) custody, and alternating (serial) or joint custody after divorce or separation of the child's parents. Even a parent who is not the primary caregiver has the obligation and right to care for the child's health ${ }^{64}$ Parents have the duty and right to protect their child from the outside world, depending on his or her level of development, maturity, age, temperament, etc. It is a traditional component of parenting and parental responsibility. Protection may be understood as anything that is done in the best interests of the child. This could be, for instance, protection against negative effects of the Internet, pedophiles, violent criminals, and persons who do not fulfil their contractual obligations properly. The law stipulates that parents play a crucial role in a child's care and upbringing and that they are supposed to be all-round role models for their children, especially for their way of life and behavior in the family (see Section 884, CC). A child must heed his/her parents (see Section 857, Sub-Section 1, CC). Until the child acquires full legal capacity, the parents have a duty and right to guide their child's behavior using methods of education as appropriate to their developing abilities, including restrictions in order to protect their morals, health, and rights, as well as the rights of others and public order. The child is obliged to conform to such methods (Section 857, Sub-Section 2, CC). The parents also decide on the child's education and his/her career paths within the scope of parental responsibility. They always consider the child's opinion in relation to his/her participatory rights, skills, and talents (see Section 880, Sub-Section 2, CC).

\subsection{The best interests and participation rights of the child}

Parents must exercise the obligations and rights arising out of parental responsibility in keeping with the best interests and well-being of the child, and with respect to his/her participatory rights. ${ }^{65} \mathrm{~A}$ child is neither the "property" of his/her parents, nor the passive object of parental responsibility. Children have participatory rights that are guaranteed by the Convention on the Rights of the Child (art. 12), which include the rights to:

a) be informed;

b) express their views and wishes;

c) influence, by his or her opinion, decisions; and

d) completely determine, by his or her opinion, decisions.

To realize these participatory rights, a child must have relevant information. The Civil Code also provides that before making a decision that affects the interests of the 
child, the parents shall inform the child of everything that is necessary for the child to know in order to form his/her own opinion on a given matter and communicate it to the parents; this does not apply if the child is unable to properly receive the message, or form his/her own opinion, or communicate it to his/her parents; the parents shall pay due attention to the child's opinion and take the child's opinion into account while making a decision (Section 875, Sub-Section 2, CC). The court has a similar information obligation toward the child, if it decides on a child's case (see Section 867, CC). The child must receive information on all the possible consequences of compliance with his/her view, or of any decision in a case or matter that concerns him/her.

To strengthen the participatory rights of the child, the Civil Code establishes a rebuttable presumption of the law, according to which a child aged over 12 years is presumed to be able to receive information and form and communicate his/her own opinion (Section 867, Sub-Section 2, the second sentence, CC). The court pays due attention to the opinion of the child. However, it must always pursue the best interests and welfare of the child.

\section{Family solidarity and maintenance}

\subsection{General}

The Civil Code respects the general principle of family solidarity. Several provisions in Book Two-Family Law protect weaker parties, for instance within the concept of community property of spouses (Section $708 \mathrm{ff}, \mathrm{CC}$ ), common lease of a flat (Section 745, CC), and things forming the usual equipment of family household (Section 698, CC), among others. Special attention is paid to maintenance duty between family members. The Civil Code regulates maintenance duty between spouses (Section 697 ff, CC) and ex-spouses (Section $760 \mathrm{ff}$, CC; for details see above) ${ }^{66}$ and toward the unmarried mother of the child (Section 920, see above), and especially between relatives in the direct line. The most detailed regulation is devoted to the maintenance duty of parents and grandparents toward children (Section $910 \mathrm{ff}, \mathrm{CC}$ ).

\subsection{Maintenance duty toward children}

The maintenance duty of parents toward children has not traditionally been a part of parental responsibility as both parents have a duty to maintain and support their child until he/she can make a living (Section 911, CC). The scope of maintenance is supposed

66 The Act on Registered Partnership provides rules for maintenance between current and former registered partners of the same sex, like the Civil Code does for spouses and ex-spouses (Sections 10, 11,12 ARP). 
to fall within the extent of the same standard of living (Section 915, CC) including the option of making savings out of maintenance (Section 917, CC). Thus, the Civil Code fully respects the principle of solidarity and the non-consumption aspect of maintenance.

To avoid a situation where this remains a mere "law in the books," the legislature complemented the new legal regulation with other effective elements by responding to two key problems confronted in practice:

a) detection of the income and property of the parents, especially when they get cash-in-hand, pay for unreported work, when they are self-employed, etc.;

b) the enforcement of judgments ordering maintenance duty.

First, in order to detect income, the lawmakers introduced the legal presumption of the income of the liable parent (or grandparent) in order to improve the child's position. The law states that a parent must prove his/her income in court by submitting documents necessary for the evaluation of his/her property and must enable the court to find out other facts that are necessary for decision-making, by making the data protected by special acts accessible. If a parent fails to fulfill this duty, his/her average monthly earning shall be presumed to amount to the 25-multiple of the life minimum required to ensure maintenance and other fundamental personal needs of such a parent pursuant to a special act ${ }^{67}$ (Section 916, CC).

If a debtor fails to maintain and support a child, an executor shall issue a writ of execution to suspend his/her driving license. The executor will serve the writ on the driver and deliver it to the registry of drivers. The debtor, that is the driver, is not allowed to drive until he/she pays the overdue maintenance. ${ }^{68}$ Criminal law traditionally considers failure to pay mandatory maintenance a criminal offense that can be punished in various ways including imprisonment (Section 196, Criminal Code); recently, a new remedy was introduced, namely preventing a person from driving for a certain period (Section 196a, Criminal Code). ${ }^{69}$ There is a new regulation on substitute maintenance, which was passed only recently. ${ }^{70}$

\section{On protection against domestic violence}

It is necessary to mention civil law provisions against domestic violence. ${ }^{71}$ The law sets forth that if a house or flat where the family household of the spouses is situated becomes intolerable for them to dwell jointly because of physical or mental violence against the

67 Act No. 110/2006 Coll., on Living and Subsistence Level.

68 Act No. 120/2001 Coll., on Enforcement Officials and their Activities, Section 71a.

69 Act No. 40/2009 Coll., Criminal Code.

70 Act No. 588/2020 Coll., effective on July 1, 2021.

71 The Civil Code complements the previous regulation established by a special law against domestic violence in 2006. Králíčková, Žatecká, Dávid, Kornel, 2011. 
spouse or anyone else living in the family household of the spouses, the court may, at the motion of the affected spouse, restrict or exclude the right of the other spouse for a specified period to $d w e l l$ in the house or the flat (Section 751, Sub-Section 1, CC). It is possible to proceed in the same manner in the case of divorced spouses as well as in the case when the spouses or ex-spouses live jointly elsewhere than in their family household (Section 751, Sub-Section 2, CC), and in the case of other persons than spouses, especially registered partners or cohabitees (Section 3021, CC). The restriction or exclusion of a spouse's right to live in the house or flat may last for a period of 1 month. This period may be extended for up to 6 months at the most, by the court. The court will, on a motion, decide again if there are serious reasons to do so (Section $752, \mathrm{CC}){ }^{72}$

\section{Conclusion}

As discussed in this article, the Civil Code was adopted after a long period of legislative work and protracted behind-the-scenes negotiations as Family Law was considered a relatively conservative area that is closely linked to many aspects of culture, religion, and tradition. Thus, both professionals and the public believed that the Civil Code would remain without significant changes for a reasonable period of time. Nevertheless, amendments have been made and many drafts are pending before the Parliament of the Czech Republic. Some of them are rather problematic and controversial, especially the ones proposed by the members of parliament.

No matter what speeches politicians may make in the Parliament, we trust that family law should protect all forms of families as there are no strict patterns for family life. While drafting amendments to the Civil Code in the future, more attention should be paid to the rights and duties of same-sex partners. It is a question of whether the concept of "marriage for all" discussed above would be good solution for them. As far as cohabitees are concerned, the Principles of European Family Law laid down by academics may be a good framework to follow. As regard divorce with minor children, the pending draft underlining more autonomy of the will of the child's parents, concerning the divorce of marriage, should be supported. The situation of divorcing parents will be similar to the position of non-married child's parents who can communicate and agreed on arrangements regarding the minor in harmony with the best interest of that child and without any interventions by the court. The paternalistic role of the state will no longer be as strong. Finally, there is no doubt that the general public would, with great anticipation, welcome the passage of a long-awaited bill on the Public Defender of Children's Rights ("ombudsman for children"). ${ }^{73}$

72 For more information on procedure, see Act No. 292/2013 Coll., on Special Civil Proceedings, Section $400 \mathrm{ff}$., An interim proceeding on protection against domestic violence.

73 Parliament of the Czech Republic, Chamber of Deputies, Parliamentary term No. VIII., Draft No. 894/0. 


\section{Bibliography}

BĚLOvSKÝ, P. (2009) Rodinné právo (Family Law). In Bobek, M., Molek, P., Šimíček, V. (eds.) Komunistické právo v Československu. Kapitoly z dějin bezpráví (Communist Law in Czechoslovakia. Chapters in History of Injustice). Brno: Masarykova univerzita.

Boele-Woelki, K., Ferrand, F., GonZÁlez-Beilfuss, C., JÄNTERÄ-JAREBORG, M., LOWE, N., MARTiny, D., PINTENS, W. (2007) Principles of European Family Law regarding Parental Responsibilities. Antwerpen - Oxford: Intersentia.

Boele-Woelki, K., FERRAND, F., GONZÁlez-Beilfuss, C., JÄNTERÄ-JAREborG, M., LOWE, N., Martiny, D., Pintens, W. (2004) Principles of European Family Law regarding Divorce and Maintenance Between Former Spouses. Antwerp - Oxford: Intersentia.

Boele-WoelKi, K., FerRAND, F., GonZÁlez-Beilfuss, C., JÄNTERÄ-JAREBORG, M., LOWE, N., MARTINY, D., PinTENS, W. (2013) Principles of European Family Law regarding Property Relations Between Spouses. Cambridge - Antwerp - Portland: Intersentia.

Boele-Woelki, K., FerRAND, F., GonzÁlez-Beilfuss, C., JÄNTERÄ-JAREborG, M., LOWE, N., Martiny, D., Todorova, V. (2019) Principles of European Family Law regarding the Property, Maintenance and Succession Rights and Duties of Couples in de facto Unions. Cambridge: Intersentia.

CEFL [Online]. Available at: http://ceflonline.net/principles/ (Accessed: 15 March 2021).

Czech Statistical Office n.d.a. [Online]. Available at: https://www.czso.cz/csu/czso/population (Accessed: 20 March 2021).

Czech Statistical Office n.d.b. [Online]. Available at: https://bit.ly/3i2yl0j (Accessed: 28 March 2021).

Czech Statistical Office n.d.c. [Online]. Available at: https://bit.ly/3i9M59o (Accessed: 28 March 2021).

EliÁš, K., ZuKLÍNOVÁ, M. (2001) Principy a východiska nového kodexu soukromého práva (Principles and Starting Points of the New Code of Private Law). Praha: Linde.

EliÁš, M., ZuKLÍNOVÁ, M. (2005) Návrh občanského zákoníku (Draft for the Civil Code). Praha: Ministry of Justice.

HADERKA, J. (1986) Surogační mateřství (Surrogate Motherhood). Právny obzor, No. 10.

HADERKA, J. F. (1996) The Czech Republic - New Problems and Old Worries. In Bainham, A. (ed.) The International Survey of Family Law 1996 Edition. The Hague - Boston - London: Martinus Nijhoff Publishing.

HADERKA, J. F. (2000) A Half-Hearted Family Law Reform of 1998. In Bainham, A. (ed.) The International Survey of Family Law 2000 Edition. Bristol: Jordan Publishing.

Holub, M. (2006) Registrované partnerství? Ani ryba, ani rak (Registered Partnership? Betwixt and between). Právní rozhledy.

HRuŠÁKovÁ, M. (2002) Czech Republic. In Blainpain, R. (gen. ed.) The International Encyclopaedia of Laws. The Hague/London/New York: Kluwer Law International.

HRUŠÁKOVÁ, M., KRÁlíčKOVÁ, Z. (2005) Anonymní a utajené mateřství v České republice utopie nebo realita? (Anonymous and Secret Motherhood in the Czech Republic - an Utopia, or Reality?) Právní rozhledy.

HruŠÁKovÁ, M., WestPhalovÁ, L. (2011) Czech Republic. $2^{\text {nd }}$ ed. In Blainpain, R. (gen. ed.) The International Encyclopaedia of Laws. The Hague/London/New York: Kluwer Law International. 
KORNEL, M. (2008) Přímý a nepřimý styk rodiče s dítětem (Direct and non-direct contact between the parent and the child). In Sborník příspěvků z konference Cofola [Online]. Available at: https://bit.ly/3zEnRKj (Accessed: 15 May 2021).

KRÁLÍČKOVÁ, Z. (2010) Lidskoprávní dimenze českého rodinného práva. Brno: Masarykova univerzita.

KRÁLÍČKOVÁ, Z. (2003) Adoption in the Czech Republic: Reform in the Light of the Child Welfare Laws. In Bainham, A. (ed.) The International Survey of Family Law. Bristol: Jordan Publ. Limited.

KRÁLÍČKOVÁ, Z. (2008) 'Development in Marriage and Marital Law in the Czech Republic (After the Communist take-over, Collapse of Communism and Accessing the European Union)' in Wardle, L. D., Loveless, A. S. (eds.) Marriage and Quasi-Marital Relationships in Central and Eastern Europe. Provo, BYU Academic Publishing.

KRÁLÍČKovÁ, Z. (2008) 'Tension between Legal, Biological and Social Parentage in the Light of the Best Interest of the Child', Legal Studies and Practice Journal, 16(3), pp. 275-282.

KRÁLÍČKovÁ, Z. (2009) 'Czech Family Law: The Right Time for Re-Codification' in Atkin, B. (ed.) The International Survey of Family Law 2009 Edition. Bristol: Jordan Publishing.

KrÁLÍČKovÁ, Z. (2011) 'Parentage, Parental Responsibility and Rights of the Child in the Czech Republic' in Essays in Honour of Penelope Agallopoulou. Greece, Athens: Ant. N. Sakkoulas Publishers, pp. 829-840.

KRÁLÍČKOVÁ, Z. (2014) New Family Law in the Czech Republic: Back to Traditions and Towards Modern Trends. In Atkin, B. (ed.) The International Survey of Family Law 2014 Edition. Bristol: Jordan Publishing.

KRÁLíčKovÁ, Z. (2016) Péče o zdraví nezletilého dítěte (Minor Child Healt Care). Časopis zdravotnického práva a bioetiky [Online]. Available at: https://bit.ly/3i4c3eI (Accessed: 20 May 2021).

KrÁlíčKovÁ, Z., HRUŠÁKOVÁ, M., WESTPHAlovÁ L. ET AL. (2020) Občanský zákoník II. Rodinné právo (Section 655-975). 2. vyd. Komentár̆. (Civil Code II. Family Law (Sections 655-975). $2^{\text {nd }}$ ed. Commentary). Praha: C. H. Beck.

KrálíčKovÁ, Z., Kornel, M., ZavadilovÁ, L. (2019) Czechia. In Ruggeri, L., Kunda, I., Winkler, S. (eds.) Family Property and Succession in EU Member States National Reports on the Collected Data. Croatia: Rijeka [Online]. Available at: https://bit.ly/3i7lV7v (Accessed: 27 March 2021).

KRÁLÍČKOVÁ, Z., ŽATECKÁ, E., DÁVID, D., KORNEL, M. (2011) Právo proti domácímu násilí (Law Against Domestic Violence). Praha: C. H. Beck.

Ministry OF LABOUR AND SOCIAL AfFAIRS OF THE CZECH REPUBliC (2020) The Report on the Family 2020. [Online]. Available at: https://bit.ly/3AVWVaJ (Accessed: 24 May 2021).

MoŽNÝ, I. (2011) Rodina a společnost (Family and Society). Praha: SLON.

NĚMEČKovÁ, M., KuRKIN, R., ŠTYGLEROVÁ, T. (2015) Marriages and Births in the Czech Republic. Family Pattern in the Czech Republic - First Child latest and outside marriage [Online]. Available at: https://bit.ly/3lXoWIy (Accessed: 18 February 2019).

Prague Monitor, 2016. [Online]. Available at: https://bit.ly/3ETygG4 (Accessed: 14 February 2019)

PSUTKA, J. (2015) Společné jmění manželů (Community property between the Spouses). Praha: C. H. Beck.

SCHERPE, J. M. (2016) The Present and Future of European Family Law. Cheltenham (UK) Northampton (MA, USA): Edward Elgar. 
ScHÖN, M. (2015) ,Postavení dítěte a jeho participační práva v rámci rodičovské odpovědnosti (The Position of the Child and his or her Participation Rights within Parental Responsibility) in Radvanová, S. (ed.) Rodina a dítě v novém občanském zákoníku (Family and the Child in the New Civil Code). Praha: C. H. Beck.

Scitani. [Online]. Available at: https://bit.ly/3CLGsGt (Accessed: 28 March 2021)

SöRGJERD, C. (2012) Reconstructing Marriage. The Legal Status of Relationships in Changing Society. Cambridge - Antwerp - Portland: Intersentia.

Statim. [Online]. Available at: www.statim.cz (Accessed: 13 May 2021).

VAN BUEREN, G. (2007) Children Rights in Europe. Strasbourg: Council of Europe. 